\title{
Simultaneous Hydrolysis and Fermentation of Defatted Rice Bran and Defatted Soybean Meal for Nisin Production with Engineered Lactococcus lactis
}

\author{
Jiaheng Liu,, a,b,c,\# Xiangyu He ${ }^{\text {a,b,c,\# }}$ Yuhui Du, ${ }^{\mathrm{d}}$ Itsanun Wiwatanaratanabutr, ${ }^{\mathrm{e}, \mathrm{f}}$ \\ Guangrong Zhao, ${ }^{\mathrm{a}, \mathrm{b}, \mathrm{c}}$ Hongji Zhu, ${ }^{\mathrm{a}, \mathrm{b}}$ Qinggele Caiyin, ${ }^{\mathrm{a}, \mathrm{b}}$ and Jianjun Qiao ${ }^{\mathrm{a}, \mathrm{b}, \mathrm{c}, *}, *$
}

This work aimed to study the potential of defatted rice bran (DRB) and defatted soybean meal (DSM) as carbon and nitrogen sources for Lactococcus lactis growth and nisin production. First, a maximum nisin yield of $3630 \mathrm{IU} / \mathrm{mL}$ was achieved using $40 \%$ DRB hydrolysates and $30 \%$ DSM hydrolysates, which was 1.13 times greater than that found in commercial media. Second, to simplify the operation and shorten the length of the entire process, the processes of combined hydrolysis of DRBDSM followed by fermentation, and simultaneous hydrolysis and fermentation of DRB-DSM were developed. Neutral proteinase enhanced the saccharification of DRB by cellulase and $\alpha$-amylase. Furthermore, the strategy of $\mathrm{NADH}$ oxidase expression and hemin addition was innovatively proposed to overcome the oxygen stress in a simultaneous hydrolysis and fermentation process, which could alleviate the lag period following inoculation of $L$. lactis and result in a $77.3 \%$ increase in nisin titer.

Keywords: Defatted rice bran; Defatted soybean meal; Nisin; Lactococcus lactis; Simultaneous hydrolysis and fermentation

Contact information: a: Key Laboratory of Systems Bioengineering, Ministry of Education (Tianjin University), Tianjin, 300072, China; b: School of Chemical Engineering and Technology, Tianjin University, Tianjin, 300072, China; c: Collaborative Innovation Center of Chemical Science and Engineering (Tianjin), Tianjin, 300072, China; d: Key Laboratory of Molecular Medicine and Biotherapy, School of Life Science, Beijing Institute of Technology, Beijing, China; e: Center of Excellence in Applied Biosciences, King Mongkut's Institute of Technology Ladkrabang, Bangkok, Thailand; f: Department of Plant Production Technology, Faculty of Agricultural Technology, King Mongkut's Institute of Technology, Ladkrabang, Bangkok, Thailand; ${ }^{\#}$ These authors contributed equally to this work;

*Corresponding author: jianjunq@tju.edu.cn

\section{INTRODUCTION}

Nisin, a safe and natural antimicrobial peptide, exhibits broad-spectrum antimicrobial activity against a majority of Gram-positive foodborne bacteria and some Gram-negative pathogens. It has a long and impressive history as a food preservative (Cotter et al. 2005; Barbosa et al. 2017). Additionally, nisin is also considered a novel candidate to alleviate the increasingly serious threat of antibiotic resistance. It has shown efficacy in various clinical applications, such as treatment of skin and soft tissue infections (Mygind et al. 2005; Fauci and Morens 2012), Clostridium difficile-associated diarrhea (Ali et al. 2013), and even cancer therapy (Joo et al. 2012).

Rice bran, an agricultural by-product of rice processing, is generally used for animal feed, and the potential for its global production exceeds 29.3 million tons annually (Sharif et al. 2014). Rice bran is widely used for the extraction of rice bran oil, a premium edible oil due to its health benefits (Sohail et al. 2017). However, defatted rice bran (DRB), 
the residue left after extraction of rice bran oil, contains a large amount of unexploited carbohydrates, polysaccharides, and proteins (Lee et al. 2009). Due to the advantage of its low lignin content and the less recalcitrant structure of DRB, it is possible to use DRB as a fermentable carbon source and partial nitrogen source (Gao et al. 2008). Defatted soybean meal (DSM), as a major by-product of the soybean oil, is commonly applied as a substitute for fish meal or poultry feed (Kikuchi 1999; Kim et al. 2003). The DSM is a nutrient-rich and low-priced agricultural material containing approximately $40 \%$ proteins. Due to its low cost, nutrient availability, and abundant amino acid species, DSM has the potential to be used as a fermentable nitrogen source (Dale et al. 2009; Capriotti et al. 2014; Hur and Park 2015).

Nisin is produced by certain Lactococcus lactis strains. Due to the strong adaptation to nutrient-rich environments, L. lactis loses the synthetic ability of many metabolites. Thus, it requires considerable amounts of refined sugars and high-quality nitrogen sources, which are quite an important part of the cost source for nisin fermentation (Sauer et al. 2017). The high cost of industrial medium has prompted investigations into exploring cheaper growth substrates, such as agricultural wastes (Krzywonos and Eberhard 2011; Shi et al. 2015; Hu et al. 2016; Grewal and Khare 2018) and fishery residues (Vazquez et al. 2008; Deraz et al. 2011). The authors previously demonstrated that defatted rice bran, the byproduct of the rice bran oil industry, could substitute for carbon source to enable L. lactis growth and nisin production (Liu et al. 2017a). To reduce the cost of industrial nitrogen source, defatted soybean meal, the byproduct after extraction of soy oil, was hydrolyzed to better support L. lactis growth and increase nisin production (Liu et al. 2017b). However, few studies report complete replacement of both the industrial carbon source and nitrogen source by cheaper growth substrates.

Additionally, the process of nisin production from DRB or DSM in the authors' previous research contained three stages including pretreatment, enzymatic hydrolysis, and fermentation, which is referred to as separate hydrolysis and fermentation. In recent years, there has been greater interest to simultaneously conduct the enzymatic hydrolysis and fermentation in the same reactor (Guo et al. 2018). This strategy would simplify the operation and shorten the length of the entire process. The combined process would also ameliorate the risk of bacterial contamination (Hazeena et al. 2019). Therefore, the objectives of this study were to evaluate the feasibility of DRB-DSM co-utilization for nisin production by L. lactis and develop the process of simultaneous hydrolysis and fermentation of DRB and DSM.

\section{EXPERIMENTAL}

\section{Materials}

The DRB and DSM in this study were purchased from Huayu Co., Ltd. (Qufu, China). The materials were milled using a high-speed blender and dried at $50{ }^{\circ} \mathrm{C}$ in a drying oven until the weight remained unchanged.

The nisin Z-producing strain L. lactis F44 was constructed in the authors' previous study (Zhang et al. 2014). The seed medium was used to inoculate L. lactis F44 and other recombinant $L$. lactis strains containing the following $(\mathrm{g} / 100 \mathrm{~mL})$ : yeast extract $1.5, \mathrm{NaCl}$ 0.15 , sucrose $1.5, \mathrm{MgSO}_{4} \cdot 7 \mathrm{H}_{2} \mathrm{O} 0.015, \mathrm{KH}_{2} \mathrm{PO}_{4}$ 2.0, peptone 1.5, and $\mathrm{pH} 7.2$. The overnight grown culture of $L$. lactis was inoculated into a commercial fermentative medium constituted of the following $\left(\mathrm{g} / 100 \mathrm{~mL}\right.$ ): sucrose $1.5, \mathrm{KH}_{2} \mathrm{PO}_{4} 2.0, \mathrm{MgSO}_{4} \cdot 7 \mathrm{H}_{2} \mathrm{O} 0.015$, 
$\mathrm{NaCl} 0.15$, yeast extract 1.5 , corn steep liquor 0.3 , cysteine 0.026 , peptone 1.5 , and $\mathrm{pH} 7.2$. Micrococcus flavus ATCC 10240, an indicator strain for the bioassay of nisin, was maintained at $37^{\circ} \mathrm{C}$ for $24 \mathrm{~h}$ in the indicator medium containing $(\mathrm{g} / 100 \mathrm{~mL})$ : tryptone 0.8 , $\mathrm{NaCl} 0.5$, yeast extract $0.25, \mathrm{Na}_{2} \mathrm{HPO}_{4} 0.2$, glucose 0.5 , and agar powder 1.5. Escherichia coli TG1 was cultured in a Luria-Bertani (LB) medium at $37{ }^{\circ} \mathrm{C}$ for plasmids preparation and enrichment.

The enzymes for saccharification of DRB included cellulase, hemicellulose, and $\alpha$ amylase. Cellulase was kindly supplied by Novozymes A/S (Beijing, China). Hemicellulase was purchased from Yuanye Bio-Technology (Shanghai, China), and $\alpha-$ amylase was purchased from Aobox Bio-Technology (Beijing, China). Their enzyme activities as described by the supplier are 70 FPU (Filter Paper Unit)/g, 20,000 and 3,700 $\mathrm{U} / \mathrm{g}$, respectively. One FPU of cellulase activity is defined as the amount of enzyme liberating $1 \mu \mathrm{mol}$ glucose from filter paper per minute. One unit of hemicellulase activity is defined as the amount of enzyme liberating $1 \mu \mathrm{mol}$ of reducing sugar from hemicellulose per minute. One unit of $\alpha$-amylase activity is defined as the amount of enzyme liberating 1 $\mu \mathrm{mol}$ of reducing sugar from starch per hour.

The proteases used in this study included neutral protease, Proteinase K, trypsin, pepsin, and papain. Neutral protease was purchased from Doing-higher Bio-Technology (Nanning, China). Proteinase K, trypsin and pepsin were purchased from Solarbio BioTechnology (Beijing, China). Papain was purchased from Yuanye Bio-Technology (Shanghai, China). Their enzyme activities, as described by supplier, were 200,000, $40,000,250,000,3,000$, and $800,000 \mathrm{U} / \mathrm{g}$, respectively. One unit of neutral protease activity is defined as the amount of enzyme that hydrolyzes casein to produce color equivalent to $1.0 \mu \mathrm{mol}$ of tyrosine per minute (color by Folin \& Ciocalteu's Phenol Reagent). One unit of Proteinase $\mathrm{K}$ activity is defined as the amount of enzyme that hydrolyzes urea-denatured hemoglobin to produce color equivalent to $1.0 \mu \mathrm{mol}$ of Folin-positive amino acids and peptides per minute. One unit of trypsin activity is defined as the amount of enzyme that produces an increase in absorbance at $253 \mathrm{~nm}$ of 0.001 per minute using N-benzoyl-1arginine ethyl ester as substrate. One unit of pepsin activity is defined as the amount of enzyme that hydrolyzes hemoglobin to trichloroacetic acid-soluble components giving a change of 0.001 in absorbance at $280 \mathrm{~nm}$ per minute. One unit of papain activity is defined as the amount of enzyme that hydrolyzes casein to trichloroacetic acid-soluble components giving an increase in absorbance at $275 \mathrm{~nm}$ equivalent to $1 \mu \mathrm{g}$ of tyrosine at $275 \mathrm{~nm}$.

\section{Methods}

Strains construction

The primers used for gene cloning are shown in Table S1. Extraction of genomic DNA from L. lactis F44 was performed using a Bacteria Genomic DNA Extraction Kit (Tiangen Biotechnology Co., Ltd., Beijing, China). The $x y l R$ and noxE genes were obtained by polymerase chain reaction (PCR) amplification from genomic DNA with the corresponding primers. The $n p r B$ gene was obtained by PCR directly from Bacillus subtilis 168 genomic DNA. The $x y l R$, noxE, and $n p r B$ genes were assembled by overlap extension PCR using PrimeSTAR Max DNA Polymerase (Takara Biomedical Technology Co., Ltd., Beijing, China) with oligonucleotides listed in Table S1 and then ligated into the digested plasmid pLEB124 using an EasyGeno Assembly Cloning Kit (Tiangen Biotechnology Co., Ltd., Beijing, China). The ligated product pLEB124-REB was heat transformed into E. coli TG1. The plasmid pLEB124-REB was electro-transformed into L. lactis F44 after antibiotics selection. The restriction enzyme digestion and DNA sequencing were 
completed to verify the sequence of the plasmid. The strains and plasmids in this study are shown in Table S2.

\section{Pretreatment of DRB and DSM}

According to the authors' previous research, thermal pretreatments of DRB and DSM at a solid loading of $10 \%$ and $5 \%(\mathrm{w} / \mathrm{v})$, respectively, were performed at temperature of $121{ }^{\circ} \mathrm{C}$ in autoclave sterilizers with pretreatment time of $20 \mathrm{~min}$ (Liu et al. 2017a,b). Then, the pH of DRB and DSM were adjusted to 4.8 and 7.2, respectively, after the samples were cooled to room temperature. The pretreatment experiments were performed in triplicate.

\section{Enzymatic hydrolysis}

In the process of separated hydrolysis of DRB and DSM for fermentation (SHRSF), enzymatic hydrolysis of DRB was carried out after thermal pretreatment. Then, the $\mathrm{pH}$ was adjusted to 4.8, and $30 \mathrm{FPU} / \mathrm{g}$ of cellulase and $150 \mathrm{U} / \mathrm{g}$ of hemicellulase were added. The enzymatic hydrolysis was processed for $45 \mathrm{~h}$ at $40{ }^{\circ} \mathrm{C}$ and $100 \mathrm{rpm}$. Next, $150 \mathrm{U} / \mathrm{g}$ of $\alpha-$ amylase was added. The enzymatic hydrolysis was processed at $50^{\circ} \mathrm{C}$ and $\mathrm{pH} \mathrm{5.6,100 \textrm {rpm }}$ for $3 \mathrm{~h}$. Then, both the DRB and DSM supernatants were separated by centrifugation at $6,580 \times \mathrm{g}$ for $15 \mathrm{~min}$. Enzymatic hydrolysis of DSM was performed at $40{ }^{\circ} \mathrm{C}, 100 \mathrm{rpm}$ for $10 \mathrm{~h}$ after $10000 \mathrm{U} / \mathrm{g}$ of neutral protease was added. Then, the supernatants DSM were separated by centrifugation at $6,580 \times \mathrm{g}$ for $15 \mathrm{~min}$. The supernatants were stored at $4{ }^{\circ} \mathrm{C}$ as fermentable constituents. All enzyme solutions were filter sterilized through a $0.22-\mathrm{mm}$ syringe filter before use.

In the combined hydrolysis of DRB and DSM for fermentation (CHRSF), the pretreated samples, DRB and DSM, were added together into 250-mL Erlenmeyer flasks. The solid loading of DRB and DSM were $10 \%(\mathrm{w} / \mathrm{v})$ and $5 \%(\mathrm{w} / \mathrm{v})$, respectively. An amount of $30 \mathrm{FPU} / \mathrm{g}$ cellulase and $150 \mathrm{U} / \mathrm{g}$ hemicellulase were added. The enzymatic hydrolysis was processed at $40{ }^{\circ} \mathrm{C}$ and $\mathrm{pH} 4.8,100 \mathrm{rpm}$ for $45 \mathrm{~h}$. Then, $150 \mathrm{U} / \mathrm{g}$ of $\alpha$ amylase was added for enzymatic hydrolysis with $\mathrm{pH} 5.6$ at $50{ }^{\circ} \mathrm{C}, 100 \mathrm{rpm}$ for $3 \mathrm{~h}$. After the $\mathrm{pH}$ was adjusted to $7.2,10000 \mathrm{U} / \mathrm{g}$ of neutral protease was added. The enzymatic hydrolysis was processed at $40{ }^{\circ} \mathrm{C}, 100 \mathrm{rpm}$ for $10 \mathrm{~h}$. The samples were centrifuged to obtain the supernatant of the DRB and DSM mixture.

\section{Simultaneous hydrolysis and fermentation of DRB and DSM (SHFRS)}

In SHFRS process, the DRB and DSM mixture medium was used for simultaneous hydrolysis and fermentation including the following $(\mathrm{g} / 100 \mathrm{~mL})$ : DRB 10, DSM 5, NaCl $0.15, \mathrm{KH}_{2} \mathrm{PO}_{4} 2$, cysteine $0.026, \mathrm{MgSO}_{4} \cdot 7 \mathrm{H}_{2} \mathrm{O} 0.015$, and $\mathrm{pH}$ 7.2. The DRB and DSM mixture medium was treated in an autoclave at $121{ }^{\circ} \mathrm{C}$ for $20 \mathrm{~min}$. After the medium was adjusted to room temperature, $1800 \mathrm{U} / \mathrm{g}$ of trypsin, $100 \mathrm{U} / \mathrm{g}$ of Proteinase K, $30 \mathrm{FPU} / \mathrm{g}$ of cellulase, $150 \mathrm{U} / \mathrm{g}$ of hemicellulase, and $150 \mathrm{U} / \mathrm{g}$ of $\alpha$-amylase were added. Simultaneously, $1 \mu \mathrm{g} / \mathrm{mL}$ of hemin (Sigma-Aldrich, St. Louis, MO, USA) was added to the DRB and DSM mixture media. Then, the samples were incubated at $30{ }^{\circ} \mathrm{C}$ with constant stirring at $100 \mathrm{rpm}$.

\section{Degradation of nisin by protease}

The nisin solution (4000 IU/mL) was added into $100-\mathrm{mL}$ conical flasks, and the $\mathrm{pH}$ of the solution was adjusted to the optimum $\mathrm{pH}$ of each enzyme. Then, neutral protease, trypsin, pepsin, and papain were added to the corresponding 100-mL conical flask. At the 
optimum temperature of each enzyme, the enzymatic hydrolysis was processed for $3 \mathrm{~h}$ with shaking at $100 \mathrm{rpm}$. After the $\mathrm{pH}$ was adjusted to 2.0, the nisin solution was sterilized at $121{ }^{\circ} \mathrm{C}$ for $20 \mathrm{~min}$. Then, the nisin titer was detected.

\section{Nisin titer assay}

The plate diffusion method was applied to determine nisin activity. The nisin standard used for nisin titer assay was purchased from Sigma Chemical Company (Shanghai, China). The stock solution of nisin $\left(10^{4} \mathrm{IU} / \mathrm{mL}\right)$ was prepared by mixing $0.1 \mathrm{~g}$ of nisin standard powder with $10 \mathrm{~mL}$ of $0.02 \mathrm{M} \mathrm{HCl}$ solution and boiled for $5 \mathrm{~min}$. Then, the gradient nisin solutions $(25,50,100$ and $200 \mathrm{IU} / \mathrm{mL})$ were prepared by the dilution of prepared solution of nisin with $0.02 \mathrm{M} \mathrm{HCl}$ solution. To determine the nisin production, $500 \mu \mathrm{L}$ of fermentation broth was diluted with $500 \mu \mathrm{L}$ of $0.02 \mathrm{M} \mathrm{HCl}$. For desorption of cell-bound nisin, the acidified fermentation broth was boiled for $5 \mathrm{~min}$ and then centrifuged at $2400 \times \mathrm{g}$ for $5 \mathrm{~min}$. Then, the supernatant was diluted appropriately with $0.02 \mathrm{M} \mathrm{HCl}$. The indicator strain M. flavus was cultured in LB medium for $24 \mathrm{~h}$ at $37^{\circ} \mathrm{C}$ and then washed with $2 \mathrm{~mL} 0.9 \% \mathrm{NaCl}$ solution. After autoclaving, $26 \mathrm{~mL}$ of indicator medium was cooled to about $50{ }^{\circ} \mathrm{C}$, and then it was inoculated with $100 \mu \mathrm{L} \mathrm{NaCl}$ solution of M. flavus (the final concentration of the strain was $10^{7} \mathrm{CFU} / \mathrm{mL}$ ). The indicator medium was poured into a sterile plate and placed at room temperature for solidification. Then the plates were placed at $4{ }^{\circ} \mathrm{C}$ overnight for precultivation. Eight wells of each plate were obtained by using a 7mm-diameter hole punch to remove agar. Then, $100 \mu \mathrm{L}$ standard nisin solutions and test samples were added into the individual well. The diameter of inhibition zone was measured by using a vernier caliper after the plates were incubated at $37{ }^{\circ} \mathrm{C}$ for $24 \mathrm{~h}$. The regression equation was obtained by processing the data from standard nisin solutions. Each sample was performed in triplicate.

\section{Analysis methods}

Two methods were used to detect the growth of L. lactis. One was to measure the optical density (OD) by using TU-1810 spectrophotometer (Beijing Purkinje General Instrument Co., Ltd., Beijing, China) at $600 \mathrm{~nm}$, and the other involved detecting colonyforming units (CFU) using the plate counting method. In the simultaneous hydrolysis and fermentation, the fermentation broth was appropriately diluted with $0.9 \% \mathrm{NaCl}$ solution. Then, the $100 \mu \mathrm{L}$ fermentation broth was spread onto the seed medium agar plates. The CFU was detected by the plate counting method after $24 \mathrm{~h}$. Each sample was performed in triplicate. The 3,5-dinitrosalicylic acid (DNS) method (Miller 1959) was applied to detect the concentration of total reducing sugars (TRS). The $\mathrm{pH}$ value was monitored by a $\mathrm{pH}$ meter. The nitrogen solubility index (NSI) was defined as the percentage of soluble nitrogen to total nitrogen. The NSI was determined based on the method of Mune Mune and Minka (2017). The molecular weight distribution of peptides in fermentation was monitored according to the method of Liu et al. (2017b).

\section{RESULTS AND DISCUSSION}

\section{Optimization of DRB and DSM Hydrolysates amounts in SHRSF process}

To verify whether the use of DRB as a carbon source and DSM as a nitrogen source can ensure the normal growth of L. lactis and nisin production, separated hydrolysis of DRB and DSM was initially adopted (Fig. 1A). Hydrolysis of DRB and DSM was 
performed according to the previous reports of Liu et al. (2017a,b). The TRS concentration in DRB hydrolysates was $43.8 \mathrm{~g} / \mathrm{L}$, and the NSI of $78.2 \%$ in DSM hydrolysates was achieved using neutral protease. Then, DRB and DSM hydrolysates were mixed in different proportions, and inorganic salts required for L. lactis growth including $20 \mathrm{~g} / \mathrm{L}$ of $\mathrm{KH}_{2} \mathrm{PO}_{4}, 1.5 \mathrm{~g} / \mathrm{L}$ of $\mathrm{NaCl}$, and $0.15 \mathrm{~g} / \mathrm{L}$ of $\mathrm{MgSO}_{4} \cdot 7 \mathrm{H}_{2} \mathrm{O}$ were added. After sterilization, fermentation was carried out using L. lactis F44, a nisin producing strain. The amounts of DRB hydrolysates and DSM hydrolysates were optimized based on the nisin yield at $8 \mathrm{~h}$. As shown in Table 1, the maximum nisin yield was up to $3315 \mathrm{IU} / \mathrm{mL}$ with $30 \% \mathrm{DSM}$ hydrolysates and 40\% DRB hydrolysates.

Table 1. Effect of DRB and DSM Hydrolysates Amounts on Nisin Production in SHRSF Process

\begin{tabular}{|c|c|c|c|c|c|c|}
\hline \multirow{2}{*}{\multicolumn{2}{|c|}{ Nisin $(\mathrm{IU} / \mathrm{mL})^{*}$}} & \multicolumn{5}{|c|}{ DSM hydrolysates } \\
\hline & & $10 \%$ & $20 \%$ & $30 \%$ & $40 \%$ & $50 \%$ \\
\hline \multirow{5}{*}{$\begin{array}{c}\text { DRB } \\
\text { hydrolysates }\end{array}$} & $10 \%$ & $713 \pm 24$ & $946 \pm 30$ & $1129 \pm 43$ & $1108 \pm 67$ & $1275 \pm 59$ \\
\hline & $20 \%$ & $1354 \pm 55$ & $1759 \pm 79$ & $1896 \pm 84$ & $1955 \pm 94$ & $\begin{array}{c}1943 \pm \\
114\end{array}$ \\
\hline & $30 \%$ & $\begin{array}{c}1987 \pm \\
121\end{array}$ & $\begin{array}{c}2254 \pm \\
122\end{array}$ & $\begin{array}{c}2574 \pm \\
167\end{array}$ & $2716 \pm 74$ & $\begin{array}{c}2814 \pm \\
196\end{array}$ \\
\hline & $40 \%$ & $\begin{array}{c}2712 \pm \\
112\end{array}$ & $\begin{array}{c}2919 \pm \\
172\end{array}$ & $\begin{array}{c}3315 \pm \\
114\end{array}$ & $\begin{array}{c}3277 \pm \\
145\end{array}$ & $\begin{array}{c}3241 \pm \\
158\end{array}$ \\
\hline & $50 \%$ & $2549 \pm 74$ & $\begin{array}{c}2835 \pm \\
156\end{array}$ & $\begin{array}{c}3017 \pm \\
125\end{array}$ & $2714 \pm 98$ & $\begin{array}{c}2654 \pm \\
132\end{array}$ \\
\hline
\end{tabular}

\section{The Fermentation Performance of F44 in SHRSF Process}

To evaluate fermentation performance with DRB hydrolysates and DSM hydrolysates as the sole carbon source and nitrogen source for nisin production by L. lactis F44, shake-flask fermentation was performed and the cell density, $\mathrm{pH}$ value, and nisin production were monitored in the SHRSF process. At the same time, the commercial medium for nisin production was also accomplished as comparative performance data (Fig. 2). F44 showed a lower growth rate for the first $8 \mathrm{~h}$ in the SHRSF medium, which may be related to certain fermentation inhibitors in the DRB and DSM hydrolysates when compared to the commercial fermentation medium. The hydrolysates of cottonseed meal and wheat bran could inhibit the growth of industrial microorganisms in the early stage (Heer and Sauer 2008). The final bacterial concentration of F44 for the commercial medium and SHRSF medium were not much different. The commercial medium had a maximum amount of nisin titer of $3211 \mathrm{IU} / \mathrm{mL}$ at $8 \mathrm{~h}$, and $3630 \mathrm{IU} / \mathrm{mL}$ at $10 \mathrm{~h}$. This indicated that L. lactis F44 could produce more nisin in the SHRSF medium per $\mathrm{mL}$ of biomass. This may be due to the presence of a small amount of galactose in the SHRSF medium, which has been shown to promote the early biosynthesis of nisin by increasing the transcriptional level of nisZ (the gene encoding the precursor peptide of nisin) (Cheigh et al. 2005). In contrast, the accumulation of lactic acid during the growth of L. lactis leads to decrease the $\mathrm{pH}$ of the fermentation broth, which seriously affects the growth of the cells and even causes the death of the cells. Under acidic conditions, the carbon metabolism pathway of L. lactis is changed and the strains tend to increase the utilization of other monosaccharides, especially galactose (Upreti and Metzger 2007; Cretenet et al. 2011). 


\section{bioresources.com}

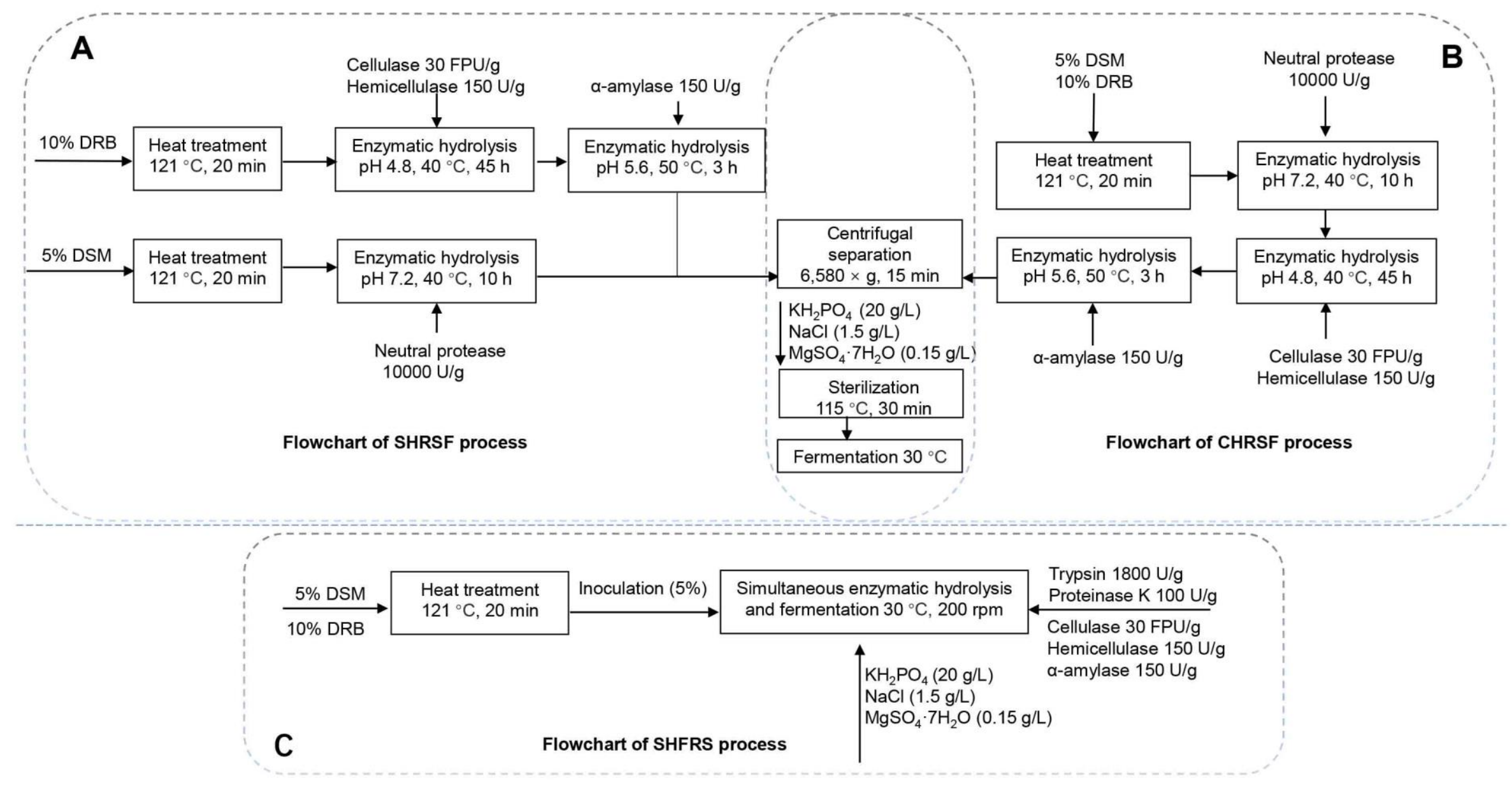

Fig. 1. Flowchart of the process for nisin production: (A) SHRSF: separated hydrolysis of DRB and DSM for fermentation; (B) CHRSF: combined hydrolysis of DRB and DSM for fermentation; (C) SHFRS: simultaneous hydrolysis and fermentation of DRB and DSM 


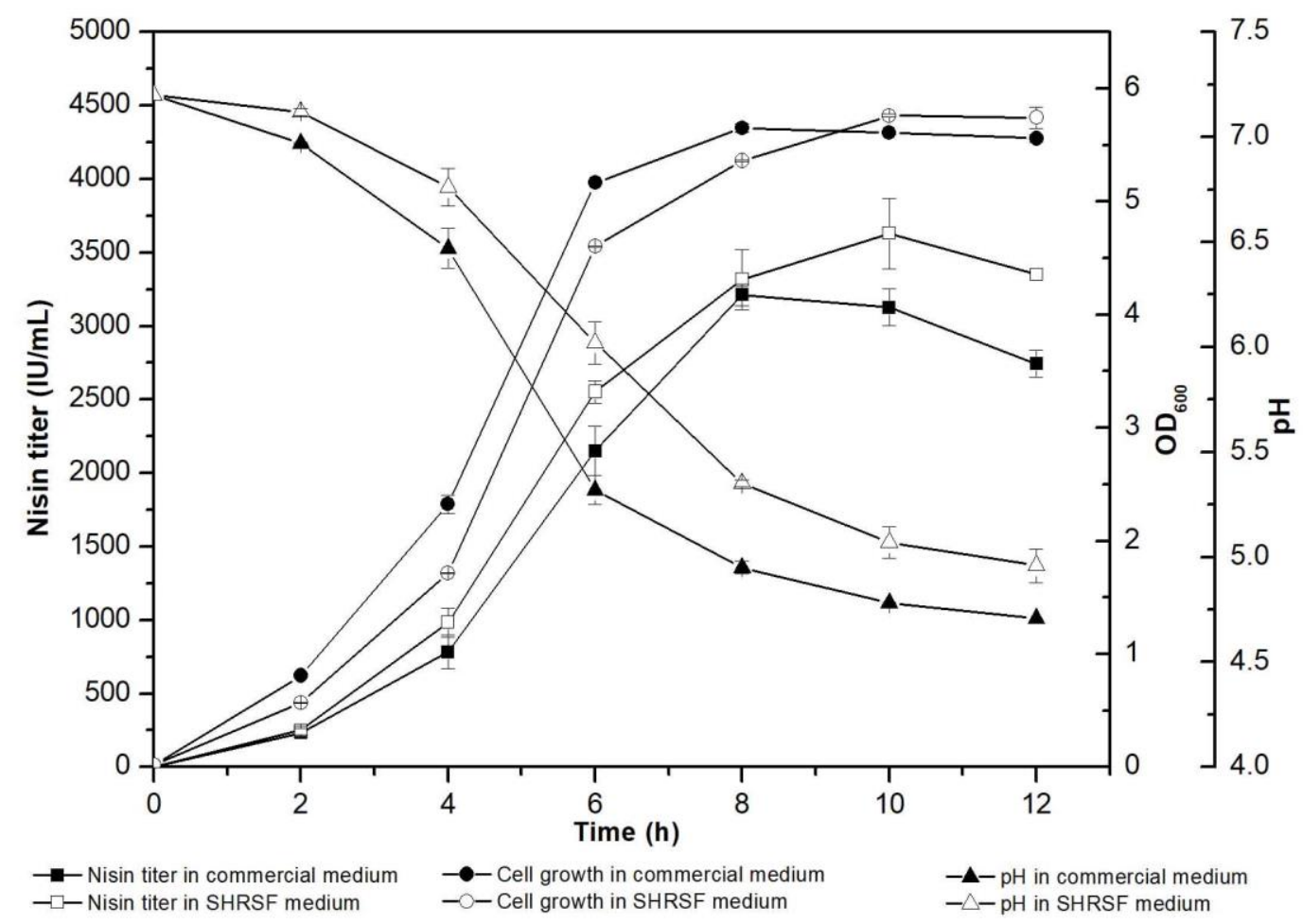

Fig. 2. Time profile of nisin titer, cell density, and $\mathrm{pH}$ of L. lactis F44 cultured in SHRSF medium and commercial fermentation medium; error bars represent standard deviations from three parallel replicates

Based on the findings, other monosaccharides in the SHRSF medium may promote the activity of the strain under acidic conditions. In addition, in the SHRSF medium, the rate of descent of $\mathrm{pH}$ was remarkably lower than that of the commercial fermentation medium, and the final $\mathrm{pH}$ of the SHRSF fermentation medium was also higher than that of the commercial medium. Some buffer substances may have been present in the SHRSF medium; further study is needed to confirm this finding.

The results of this study indicated that DRB hydrolysate and DSM hydrolysate could completely provide the carbon and nitrogen sources needed for the growth and production of L. lactis F44. Refined sugar and a high-quality nitrogen source did not need to be added to the prepared medium. The medium was shown to have the potential to reduce the industrial cultivation cost of L. lactis and the cost of nisin production.

\section{The Distribution of Peptides Before and After Fermentation of the SHRSF Medium}

For L. lactis, the nitrogen source that can be utilized is mainly present in the medium in the form of soluble peptides and free amino acids. The availability of soluble peptides is related to the molecular weight of peptides. Some peptides with large molecular weight can only be hydrolyzed by proteases into oligopeptides containing 4 to 18 amino acids in the oligopeptide transport system of L. lactis before they can be used for absorption and utilization (Sanz et al. 2001; Picon et al. 2010). The distribution of peptides of different molecular weights before and after fermentation of the SHRSF medium was observed, and the findings are shown in Table 2. In the original SHRSF medium, almost all peptides had 
molecular weights above $4 \mathrm{kDa}$, indicating that the peptides in SHRSF medium were hard to be directly absorbed and utilized by L. lactis. After fermentation, the peptides above 4 $\mathrm{kDa}$ were not detected and the content of 2 to $4 \mathrm{kDa}$ peptide was low, showing that L. lactis can effectively degrade and utilize the nitrogen source in SHRSF medium.

Table 2. Molecular Weight Distribution of Peptides of SHRSF Medium Before and After Fermentation

\begin{tabular}{|c|c|c|c|c|c|c|c|c|c|}
\hline $\begin{array}{c}\text { Weight } \\
(\mathrm{kDa})\end{array}$ & $\begin{array}{c}0 \text { to } \\
0.3\end{array}$ & $\begin{array}{c}0.3 \text { to } \\
0.6\end{array}$ & $\begin{array}{c}0.6 \text { to } \\
1\end{array}$ & $\begin{array}{c}1 \text { to } \\
2\end{array}$ & $\begin{array}{c}2 \text { to } \\
4\end{array}$ & $\begin{array}{c}4 \text { to } \\
8\end{array}$ & $\begin{array}{c}8 \text { to } \\
12\end{array}$ & $\begin{array}{c}12 \text { to } \\
20\end{array}$ & $\begin{array}{c}> \\
20\end{array}$ \\
\hline Before (\%) & ND $^{\mathrm{a}}$ & ND & ND & ND & ND & 29.3 & 21.4 & 28.2 & $\begin{array}{c}21 . \\
1\end{array}$ \\
\hline After (\%) & 4.2 & 21.3 & 63.2 & 6.2 & 5.1 & ND & ND & ND & ND \\
\hline a ND: not detected
\end{tabular}

\section{Development of CHRSF Process}

In SHRSF process, DRB and DSM need to be separately hydrolyzed to prepare an enzymatic hydrolysate. This causes problems including cumbersome operation and complicated process flow.

To further reduce costs, enzymatic hydrolysis of the DRB and DSM mixture was applied. The components of DRB and DSM are cross-linked. The DRB contains a small amount of protein and DSM contains a small amount of polysaccharide. Therefore, the CHRSF process was developed to not only simplify the process but also to make the full use of the nutrients of DRB and DSM. The process flow is shown in Fig. 1B.

\section{Hydrolytic Effect of Neutral Protease on the Cellulase and $\alpha$-amylase}

In the CHRSF process, proteases and saccharification enzymes (cellulase, hemicellulase and $\alpha$-amylase) are combined to digest DRB and DSM mixtures. Because glucoamylase is a protein, it is necessary to ensure that protease does not degrade glucoamylase. Therefore, the saccharification effect of protease on cellulase and $\alpha$-amylase was verified according to the reducing sugar yield.

With the concentration gradient of different neutral proteases, $30 \mathrm{FPU} / \mathrm{g}$ of cellulase and $150 \mathrm{U} / \mathrm{g}$ of $\alpha$-amylase were used to digest $\mathrm{DRB}$ under the optimum $\mathrm{pH}$ and temperature conditions, respectively. The cellulase digestion time was $40 \mathrm{~h}$, and the enzymatic hydrolysis time of $\alpha$-amylase was $4 \mathrm{~h}$. The authors found that the addition of neutral protease not only did not reduce the yield of reducing sugar but also increased the TRS yield with the increasing of neutral protease, indicating that the neutral protease had a positive effect on the saccharification of DRB by cellulase and $\alpha$-amylase. Without neutral protease, the yield of TRS obtained from enzymatic hydrolysis of DRB by cellulase and $\alpha$ amylase was $8.3 \mathrm{~g} / \mathrm{L}$ and $12.8 \mathrm{~g} / \mathrm{L}$, respectively.

After the addition of $10000 \mathrm{U} / \mathrm{g}$ of neutral protease, the total reducing sugar yield was increased to $10.3 \mathrm{~g} / \mathrm{L}$ and $17.8 \mathrm{~g} / \mathrm{L}$, respectively (Fig. 3). In this study, the authors concluded that the protein in DRB was crosslinked with components such as cellulose and starch. The hydrolysis of protein components by neutral proteases reduced the degree of crosslinking, making cellulose and starch in DRB more susceptible to combine cellulase and $\alpha$-amylase to enhance the effect of saccharification. In addition, protease can act as a surfactant, which promotes the enzymatic hydrolysis of glucoamylase (Liang et al. 2011). 


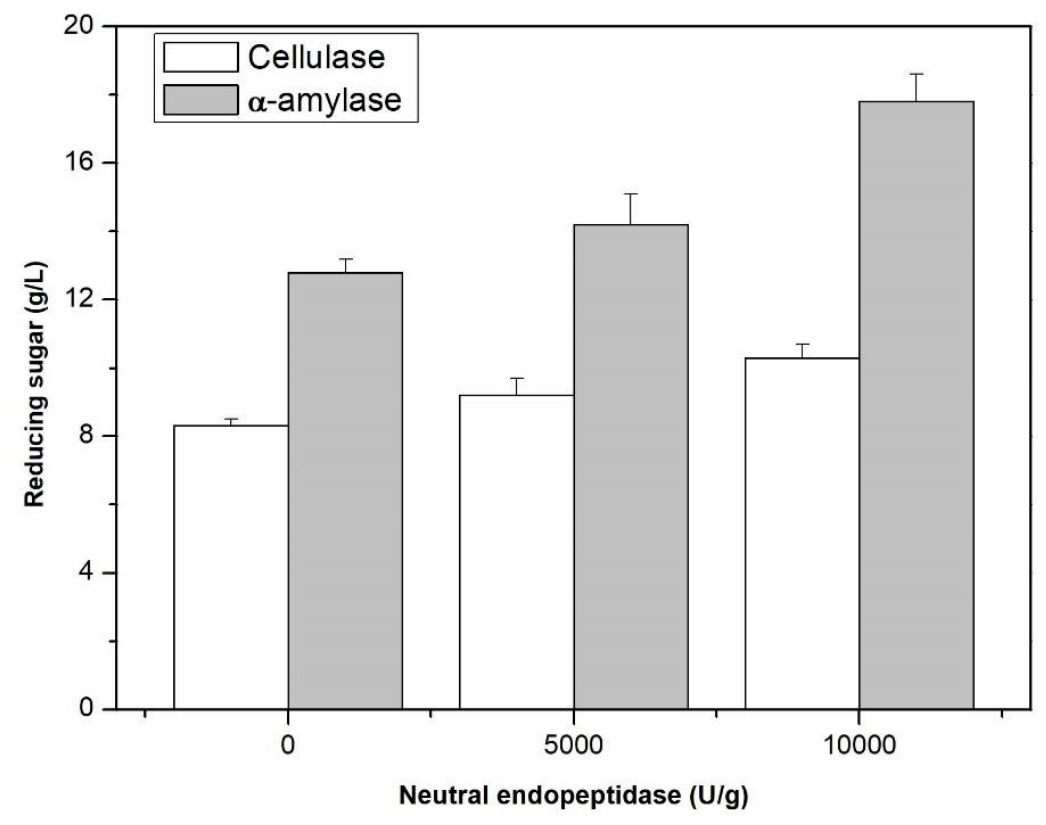

Fig. 3. Effect of neutral protease on enzymatic saccharification of cellulase and $\alpha$-amylase; the enzyme dose was 30 FPU of cellulase and $150 \mathrm{U}$ of $\alpha$-amylase per $\mathrm{g}$ solids; error bars represent standard deviations from three parallel replicates.

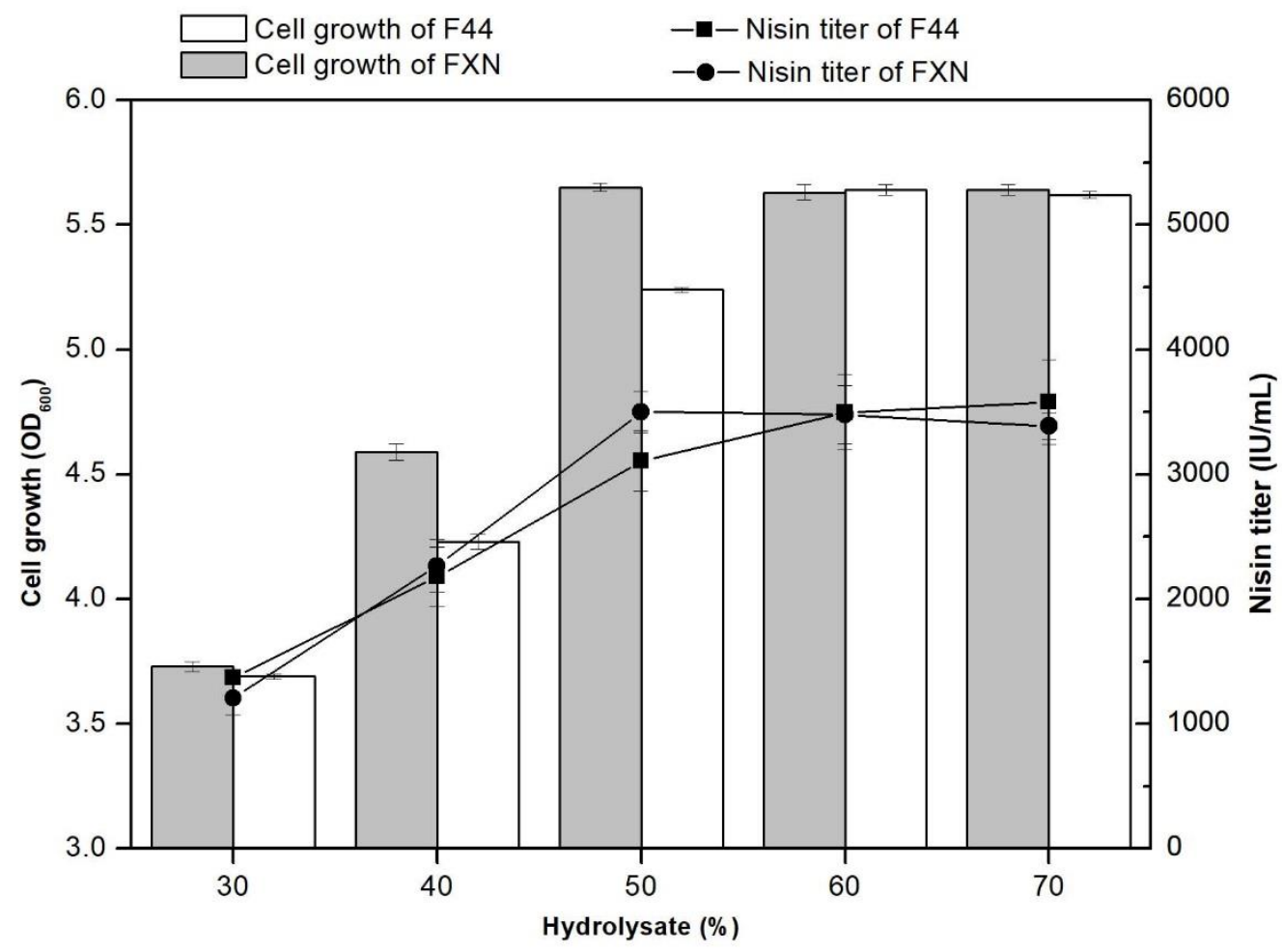

Fig. 4. Effects of hydrolysates dosage on cell density and nisin titer of L. lactis F44 and FXN; the average data of triplicate experiments are presented; error bars represent the standard deviation of triplicate experiments. 


\section{Construction of Engineered Strain L. lactis FXN and Fermentation in CHRSF Medium}

The authors' previous studies showed that the ability of xylose utilization could be enhanced in DRB hydrolysate by improving the activity of the xylose transcriptional regulator xylR (Liu et al. 2017a). In addition, the proteolytic function of L. lactis F44 can increase the utilization of nitrogen sources in the DSM and reduce the amount of DSM hydrolysate (Liu et al. 2017b). Therefore, xylR gene in L. lactis F44 was overexpressed, and the nprB gene, encoding extracellular protease $\mathrm{NprB}$ derived from B. subtilis, was heterologously introduced into F44. As a result, the engineered strain L. lactis FXN was constructed. In $=$ CHRSF process, the fermentation performances of L. lactis F44 and FXN were compared with different enzymatic hydrolysate contents (Fig. 4). The results showed that the engineered strain FXN could obtain the highest nisin yield and the highest amounts of bacteria with 50\% enzymatic hydrolysate in CHRSF medium. The nisin yield and the cell density were equivalent to that of F44 with $60 \%$ of the enzymatic hydrolysate content. It indicated that the requirement of the FXN strain for the enzymatic hydrolysate content was lower than that of F44, which was beneficial to reducing the amount of the medium and the production cost of the nisin.

\section{Development of SHFRS process}

At present, simultaneous saccharification and fermentation (SSF) is relatively mature in the production of ethanol by Saccharomyces cerevisiae using lignocellulose. SSF aims to complete the saccharification and fermentation process in one step. It can simplify the production process by reducing the number of reaction tanks and operating units compared to separate hydrolysis and fermentation. The total investment cost is estimated to be reduced by more than 20\% (Wingren et al. 2003). A further advantage is that the enzymatic hydrolysate can be rapidly utilized by the strain, reducing product inhibition by the enzymatic process. In this study, the cellulose and starch components of DRB were needed to convert into fermentable sugars; additionally, the macromolecular proteins of DSM were needed to hydrolyze into a nitrogen source that could be used for L. lactis. Therefore, the SHFRS process was proposed as shown in Fig. 1C. In this process, inorganic salt ions were added into enzymatic hydrolysate before the heat treatment, then enzymatic hydrolysis and fermentation were simultaneously carried out. The unfavorable factors of the process were that the optimal $\mathrm{pH}$ of enzyme was different from fermentation process, and the optimum $\mathrm{pH}$ of protease and glucoamylase were also different. However, the $\mathrm{pH}$ of the fermentation broth constantly decreased with the production of lactic acid during the growth of L. lactis, which had a beneficial effect on many enzymes used in the experiment. In addition, because the enzymatic hydrolysate can be used for growth of strains in time, the process also has the potential to increase the enzymatic efficiency.

\section{Screening for Proteases in SHFRS Process}

Because the protease and the fermentation product nisin coexist in the fermentation system in SHFRS process, it is crucial to screen for proteases that do not degrade nisin. Therefore, the degradation of nisin by neutral protease, trypsin, pepsin, Proteinase K, and papain was studied (Fig. 5), and the enzymatic hydrolysis effect on DSM was observed (Fig. S1). Neutral protease had a strong degradation effect on nisin. After treatment with neutral protease for $3 \mathrm{~h}$, the nisin titer decreased to $26.7 \%$ of the amount found in the control group. Pepsin and papain treatment also reduced nisin activity. Treatment with trypsin and Proteinase $\mathrm{K}$ had little effect on nisin activity. Next, the enzymatic hydrolysis of DSM by 
neutral protease, trypsin, and Proteinase K was studied. After digestion, the NSI of DSM by using trypsin and Proteinase $\mathrm{K}$ were lower than that of neutral protease. In addition, trypsin was only active in the $\mathrm{pH}$ range of 6 to 8 whereas the optimum $\mathrm{pH}$ range of Proteinase $\mathrm{K}$ was broadened from 4 to 12 . Therefore, considering the optimum $\mathrm{pH}$ of the two enzymes and the enzymatic efficiency to DSM, both proteases were used in SHFRS process.

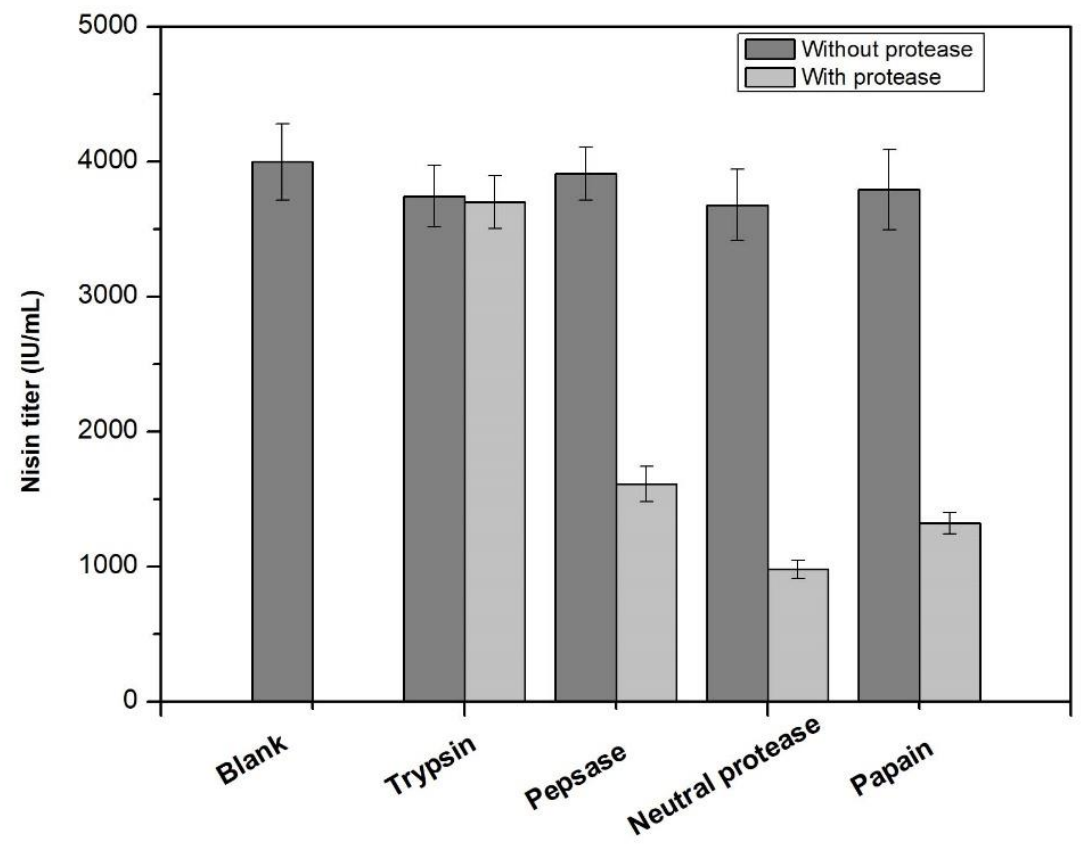

Fig. 5. Effect of protease on nisin degradation; the enzyme dose was $10 \mathrm{U}$ per milliliter of nisin solution; error bars represent the standard deviation of triplicate experiments

\section{Effect of noxE Overexpression Combined with Addition of Hemin in SHFRS fermentation}

At present, the fermentation of L. lactis and the nisin production in industry are performed under anaerobic conditions. Due to the low oxygen utilization and tolerance of L. lactis, excessively high dissolved oxygen is unfavorable for the growth of the strain. In the SHFRS, the process must be completed under stirring conditions to ensure sufficient contact of the enzymes and feedstocks. Therefore, it is necessary to increase the dissolved oxygen of the simultaneous enzymatic hydrolysis and fermentation system. In addition, related studies have shown that the oxygen supply is helpful for the saccharification of lignocellulosic biomass (Bi et al., 2016), and the respiration of the cell was stimulated with hemin to extensively enhance the nisin production (Kordikanlioglu et al. 2015). In SHFRS process, there was a certain delay in the growth of the strain in the early stage, probably due to the high dissolved oxygen in the simultaneous enzymatic hydrolysis system. The authors further overexpressed the noxE-encoded NADH oxidase into L. lactis FXN for constructing the recombinant strains FXNE and added $1 \mu \mathrm{g} / \mathrm{mL}$ of hemin to the fermentation system to activate the aerobic respiratory chain of L. lactis. The results showed that this strategy effectively alleviated the growth retardation of the strain in the early stage. The nisin yield of the reconstituted strain FXNE reached $1870 \mathrm{IU} / \mathrm{mL}$ at $16 \mathrm{~h}$, which was $70 \%$ higher than the highest nisin yield without adding hemin (Fig. 6). In 
addition, the nisin yield of the SHFRS process was remarkably lower than that of the SHFRS and CHRSF processes. This might have been due to insufficient nutrient supply during simultaneous enzymatic fermentation, but after adding $5 \mathrm{~g} / \mathrm{L}$ of glucose and $5 \mathrm{~g} / \mathrm{L}$ of peptone to the SHFRS medium, there was no remarkable change in nisin production. Therefore, it may be possible that the DRB and DSM solid residues in SHFRS process had an adsorption effect on nisin, resulting in a low level of free nisin detected. In the future, the process or the nisin separation method can be further improved to enhance economic benefits.

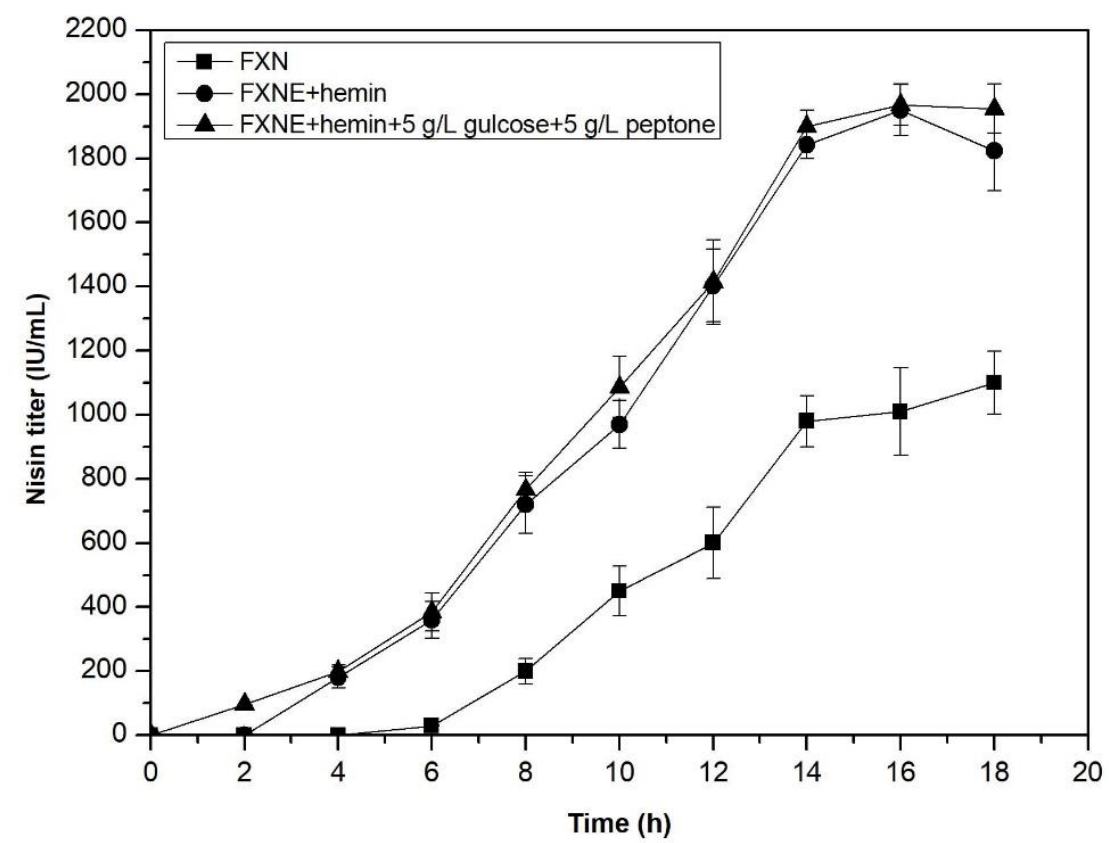

Fig. 6. Nisin production curves of $L$. lactis FXN and FXNE in SHFRS process; average data of triplicate experiments are presented; error bars represented the standard deviation of triplicate experiments

\section{CONCLUSIONS}

1. Three processes including separate hydrolysis of DRB and DSM for fermentation (SHRSF), combined hydrolysis of DRB and DSM for fermentation (CHRSF), and simultaneous hydrolysis of DRB and DSM for fermentation SHFRS were applied to realize co-utilization of defatted rice bran (DRB) and defatted soy meal (DSM) with L. lactis for nisin production.

2. The maximum nisin yield was up to $3630 \mathrm{IU} / \mathrm{mL}$ with $30 \%$ DSM hydrolysates and $40 \%$ DRB hydrolysates in SHRSF process, which was 1.13 times greater than that found in commercial media.

3. The neutral protease had a positive effect on the saccharification of DRB by cellulase and $\alpha$-amylase.

4. L. lactis FXN was constructed through overexpression of XylR and heterologous expression of NrpB. The nisin yield and the cell density of FXN with $50 \%$ enzymatic 
hydrolysate were equivalent to that of F44 with $60 \%$ of the enzymatic hydrolysate content in CHRSF process.

5. The strategy of NoxE overexpression and hemin addition notably increased nisin production by enhancing the ability of L. lactis to handle oxidative stress under aerobic condition in SHFRS process.

\section{ACKNOWLEDGMENTS}

The present work was supported by the National Key Research and Development Project of China (2017YFD0201400), the National Natural Science Foundation of China (31570089, 31770076), the Funds for Creative Research Groups of China (21621004), and the Opening Project of Key Laboratory of Storage of Agricultural Products (KF2018003). Dr. Jianjun Qiao was supported by the New Century Outstanding Talent Support Program, Education Ministry of China.

\section{REFERENCES CITED}

Ali, A. H., Hale, T. W., Khasawneh, F. A., Urban, R. S., Werner, H. V., and Smalligan, R. D. (2013). "Nisin and Clostridium difficile: A potentially effective treatment for an increasingly problematic disease," The American Journal of Gastroenterology 108(4), 625. DOI: 10.1038/ajg.2012.474

Barbosa, A. A. T., Mantovani, H. C., and Jain, S. (2017). "Bacteriocins from lactic acid bacteria and their potential in the preservation of fruit products," Critical Reviews in Biotechnology 37(7), 852-864. DOI: 10.1080/07388551.2016.1262323

Bi, S., Peng, L., Chen, K., and Zhu, Z. (2016). "Enhanced enzymatic saccharification of sugarcane bagasse pretreated by combining $\mathrm{O}_{2}$ and $\mathrm{NaOH}$," Bioresource Technology 214, 692-699. DOI: 10.1016/j.biortech.2016.05.041

Capriotti, A. L., Caruso, G., Cavaliere, C., Samperi, R., Stampachiacchiere, S., Zenezini Chiozzi, R., and Lagana, A. (2014). "Protein profile of mature soybean seeds and prepared soybean milk," Journal of Agricultural and Food Chemistry 62(40), 9893 9899. DOI: $10.1021 /$ jf5034152

Cheigh, C. I., Park, H., Choi, H. J., and Pyun, Y. R. (2005). "Enhanced nisin production by increasing genes involved in nisin $\mathrm{Z}$ biosynthesis in Lactococcus lactis subsp. Lactis A164," Biotechnology Letters 27(3), 155-160. DOI: 10.1007/s10529-004-7661-3

Cotter, P. D., Hill, C., and Ross, R. P. (2005). "Bacteriocins: Developing innate immunity for food," Nature Reviews Microbiology 3(10), 777-788. DOI: 10.1038/nrmicro1273

Cretenet, M., Laroute, V., Ulve, V., Jeanson, S., Nouaille, S., Even, S., Piot, M., Girbal, L., Le Loir, Y., Loubiere, P., et al. (2011). "Dynamic analysis of the Lactococcus lactis transcriptome in cheeses made from milk concentrated by ultrafiltration reveals multiple strategies of adaptation to stresses," Applied and Environmental Microbiology 77(1), 247-257. DOI: 10.1128/AEM.01174-10

Dale, B. E., Allen, M. S., Laser, M., and Lynd, L. R. (2009). "Protein feeds coproduction in biomass conversion to fuels and chemicals," Biofuels, Bioproducts and Biorefining 3(2), 219-230. DOI: 10.1002/bbb.132 
Deraz, S. F., El-Fawal, G. F., Abd-Ellatif, S. A., and Khalil, A. A. (2011).

"Autohydrolysed Tilapia nilotica fish viscera as a peptone source in bacteriocin production," Indian Journal of Microbiology 51(2), 171-175. DOI: 10.1007/s12088011-0119-0

Fauci, A. S., and Morens, D. M. (2012). "The perpetual challenge of infectious diseases," New England Journal of Medicine 366(5), 454-461. DOI: 10.1056/NEJMra1108296

Gao, M. T., Kaneko, M., Hirata, M., Toorisaka, E., and Hano, T. (2008). "Utilization of rice bran as nutrient source for fermentative lactic acid production," Bioresource Technology 99(9), 3659-3664. DOI: 10.1016/j.biortech.2007.07.025

Grewal, J., and Khare, S. K. (2018). "One-pot bioprocess for lactic acid production from lignocellulosic agro-wastes by using ionic liquid stable Lactobacillus brevis," Bioresource Technology 251, 268-273. DOI: 10.1016/j.biortech.2017.12.056

Guo, H., Chang, Y., and Lee, D.-J. (2018). "Enzymatic saccharification of lignocellulosic biorefinery: Research focuses," Bioresource Technology 252, 198-215. DOI: 10.1016/j.biortech.2017.12.062

Hazeena, S. H., Nair Salini, C., Sindhu, R., Pandey, A., and Binod, P. (2019). "Simultaneous saccharification and fermentation of oil palm front for the production of 2,3-butanediol," Bioresource Technology 278, 145-149. DOI:

10.1016/j.biortech.2019.01.042

Heer, D., and Sauer, U. (2008). "Identification of furfural as a key toxin in lignocellulosic hydrolysates and evolution of a tolerant yeast strain," Microbial Biotechnology 1(6), 497-506. DOI: 10.1111/j.1751-7915.2008.00050.x

Hu, J., Lin, Y., Zhang, Z., Xiang, T., Mei, Y., Zhao, S., Liang, Y., and Peng, N. (2016). "High-titer lactic acid production by Lactobacillus pentosus FL0421 from corn stover using fed-batch simultaneous saccharification and fermentation," Bioresource Technology 214, 74-80. DOI: 10.1016/j.biortech.2016.04.034

Hur, J. M., and Park, D. H. (2015). "Making soy sauce from defatted soybean meal without the mejus process by submerged cultivation using thermophilic bacteria," Journal of Food Science and Technology 52(8), 5030-5038. DOI: 10.1007/s13197014-1536-y

Joo, N. E., Ritchie, K., Kamarajan, P., Miao, D., and Kapila, Y. L. (2012). "Nisin, an apoptogenic bacteriocin and food preservative, attenuates HNSCC tumorigenesis via CHAC1," Cancer Medicine 1(3), 295-305. DOI: 10.1002/cam4.35

Kikuchi, K. (1999). "Use of defatted soybean meal as a substitute for fish meal in diets of Japanese flounder (Paralichthys olivaceus)," Aquaculture 179 (1-4), 3-11. DOI: 10.1016/S0044-8486(99)00147-7

Kim, S., Kim, W., and Hwang, I. K. (2003). "Optimization of the extraction and purification of oligosaccharides from defatted soybean meal," International Journal of Food Science and Technology 38(3), 337-342. DOI: 10.1046/j.13652621.2003.00679.x

Kördikanlioglu, B., Simsek, O., and Saris, P. E. (2015). "Nisin production of Lactococcus lactis N8 with hemin-stimulated cell respiration in fed-batch fermentation system," Biotechnology Progress 31(3), 678-685. DOI: 10.1002/btpr.2075

Krzywonos, M., and Eberhard, T. (2011). "High density process to cultivate Lactobacillus plantarum biomass using wheat stillage and sugar beet molasses," Electronic Journal of Biotechnology 14(2), 1-9. DOI: 10.2225/vol14-issue2-fulltext-10

Lee, J. E., Seo, E. J., Kweon, D. H., Park, K. M., and Jin, Y. S. (2009). "Fermentation of rice bran and defatted rice bran for butanol production using Clostridium beijerinckii 
NCIMB 8052," Journal of Microbiology and Biotechnology 19(5), 482-490. DOI: 10.4014/jmb.0804.275

Liang, Y., Yuan, X., Zeng, G., Zhong, H., Li, H., and Wang, W. (2011). "Effects of surfactants on enzyme-containing reversed micellar system," Science China Chemistry 54(5), 715-723. DOI: 10.1007/s11426-011-4266-2

Liu, J., Ma, Z., Zhu, H., Caiyin, Q., Liang, D., Wu, H., Huang, X., and Qiao, J. (2017a). "Improving xylose utilization of defatted rice bran for nisin production by overexpression of a xylose transcriptional regulator in Lactococcus lactis," Bioresource Technology 238, 690-697. DOI: 10.1016/j.biortech.2017.04.076

Liu, J., Zhou, J., Wang, L., Ma, Z., Zhao, G., Ge, Z., Zhu, H., and Qiao, J. (2017b). "Improving nitrogen source utilization from defatted soybean meal for nisin production by enhancing proteolytic function of Lactococcus lactis F44," Scientific Reports 7(1), Article number 6189. DOI: 10.1038/s41598-017-06537-w

Miller, G. L. (1959). "Use of dinitrosalicylic acid reagent for determination of reducing sugar," Analytical Chemistry 31(3), 426-428. DOI: 10.1021/ac60147a030

Mune Mune, M. A., and Minka, S. R. (2017). "Production and characterization of cowpea protein hydrolysate with optimum nitrogen solubility by enzymatic hydrolysis using pepsin," Journal of the Science of Food and Agriculture 97(8), 2561-2568. DOI: $10.1002 /$ jsfa. 8076

Mygind, P. H., Fischer, R. L., Schnorr, K. M., Hansen, M. T., Sonksen, C. P., Ludvigsen, S., Raventos, D., Buskov, S., Christensen, B., De Maria, L., et al. (2005). "Plectasin is a peptide antibiotic with therapeutic potential from a saprophytic fungus," Nature 437(7061), 975-980. DOI: 10.1038/nature04051

Picon, A., García-Casado, M. A., and Nuñez, M. (2010). "Proteolytic activities, peptide utilization and oligopeptide transport systems of wild Lactococcus lactis strains," International Dairy Journal 20(3), 156-162. DOI: 10.1016/j.idairyj.2009.10.002

Sanz, Y., Lanfermeijer, F. C., Renault, P., Bolotin, A., Konings, W. N., and Poolman, B. (2001). "Genetic and functional characterization of $d p p$ genes encoding a dipeptide transport system in Lactococcus lactis," Archives of Microbiology 175(5), 334-343. DOI: $10.1007 / \mathrm{s} 002030100270$

Sauer, M., Russmayer, H., Grabherr, R., Peterbauer, C. K., and Marx, H. (2017). "The efficient clade: Lactic acid bacteria for industrial chemical production," Trends in Biotechnology 35(8), 756-769. DOI: 10.1016/j.tibtech.2017.05.002

Sharif, M. K., Butt, M. S., Anjum, F. M., and Khan, S. H. (2014). "Rice bran: A novel functional ingredient," Critical Reviews in Food Science and Nutrition 54(6), 807816. DOI: 10.1080/10408398.2011.608586

Shi, S., Kang, L., and Lee, Y. Y. (2015). "Production of lactic acid from the mixture of softwood pre-hydrolysate and paper mill sludge by simultaneous saccharification and fermentation," Applied Biochemistry and Biotechnology 175(5), 2741-2754. DOI: 10.1007/s12010-014-1451-8

Sohail, M., Rakha, A., Butt, M. S., Iqbal, M. J., and Rashid, S. (2017). "Rice bran nutraceutics: A comprehensive review," Critical Reviews in Food Science and Nutrition 57(17), 3771-3780. DOI: 10.1080/10408398.2016.1164120

Upreti, P., and Metzger, L. E. (2007). "Influence of calcium and phosphorus, lactose, and salt-to-moisture ratio on Cheddar cheese quality: $\mathrm{pH}$ changes during ripening," Journal of Dairy Science 90(1), 1-12. DOI: 10.3168/jds.S0022-0302(07)72603-6

Vázquez, J. A., Docasal, S. F., Prieto, M. A., González, M. A., and Murado, M. A. (2008). "Growth and metabolic features of lactic acid bacteria in media with 
hydrolysed fish viscera. An approach to bio-silage of fishing by-products," Bioresource Technology 99(14), 6246-6257. DOI: 10.1016/j.biortech.2007.12.006

Wingren, A., Galbe, M., and Zacchi, G. (2003). "Techno-economic evaluation of producing ethanol from softwood: Comparison of SSF and SHF and identification of bottlenecks," Biotechnology Progress 19(4), 1109-1117. DOI: 10.1021/bp0340180

Zhang, Y. F., Liu, S. Y., Du, Y. H., Feng, W. J., Liu, J. H., and Qiao, J. J. (2014).

"Genome shuffling of Lactococcus lactis subspecies lactis YF11 for improving nisin Z production and comparative analysis," Journal of Dairy Science 97(5), 2528-2541. DOI: $10.3168 /$ jds.2013-7238

Article submitted: March 10, 2020; Peer review completed: June 4, 2020; Revised version receive and accepted: June 28, 2020; Published: July 2, 2020.

DOI: $10.15376 /$ biores.15.3.6385-6403 


\section{APPENDIX}

\section{Supplementary Data}

Table S1. Primers Used in This Study

\begin{tabular}{|c|c|}
\hline Primers & Sequences (5 'to 3') $^{\text {') }}$ \\
\hline NprB-F & ACGTCATATGGATCCAAATGGTAGATTCCAAAATAGG \\
\hline NprB-R & TCTCTCCTAATCACTCAGTCAGACTCTGTGTCCTGA \\
\hline$X y / R-\mathrm{F}$ & CACAGAGTCTGACTGAGTGATTAGGAGAGAATGAACATG \\
\hline$X y / R-\mathrm{R}$ & CCTATATATGGATCCTGTTAAAAATAAAGAGTCTAAAAATGA \\
\hline NoxE-F & AACTTAAGTAAGCTTTGCAGAAGAGGAAGATTAGCC \\
\hline NoxE-R & CGTCTGCAGAAGCTTTTAGGACATTAGTCACAAAAAA \\
\hline
\end{tabular}

Table S2. Strains Used in This Study

\begin{tabular}{|c|c|c|}
\hline Strains & Relevant Characteristics & $\begin{array}{l}\text { Sources or } \\
\text { References }\end{array}$ \\
\hline $\begin{array}{l}\text { Lactococcus lactis } \\
\text { F44 }\end{array}$ & $\begin{array}{c}\text { Nisin Z producer, constructed through genome } \\
\text { shuffling of L. lactis YF11 }\end{array}$ & Zhang et al. 2014 \\
\hline Escherichia coli TG1 & Used for plasmid preparation & Laboratory stock \\
\hline Micrococcus flavus & $\begin{array}{l}\text { Used as an indicator strain for bioassay of } \\
\text { nisin }\end{array}$ & ATCC 10240 \\
\hline Bacillus subtilis 168 & Used for cloning heterologous protease & Laboratory stock \\
\hline L. lactis FXN & F44 harboring pLXN & This study \\
\hline L. lactis FXNE & F44 harboring pLXNE & This study \\
\hline \multicolumn{3}{|c|}{ Plasmids } \\
\hline pLEB124 & $\begin{array}{l}\text { Gram+ cloning vector with an P45 promoter } \\
\text { followed by multiple restriction sites, Em }{ }^{r}\end{array}$ & Qiao et al. 1995 \\
\hline $\mathrm{pLXN}$ & $\begin{array}{c}\text { pLEB124 carrying the } x y / R \text { gene from F44, } \\
\text { nprB gene from } B \text {. subtilis } 168, \mathrm{Em}^{\mathrm{r}}\end{array}$ & This study \\
\hline pLXNE & $\begin{array}{l}\text { pLEB124 carrying } x y / R \text { and noxE gene from } \\
\text { F44, the nprB from B. subtilis } 168, \mathrm{Em}^{r}\end{array}$ & This study \\
\hline
\end{tabular}




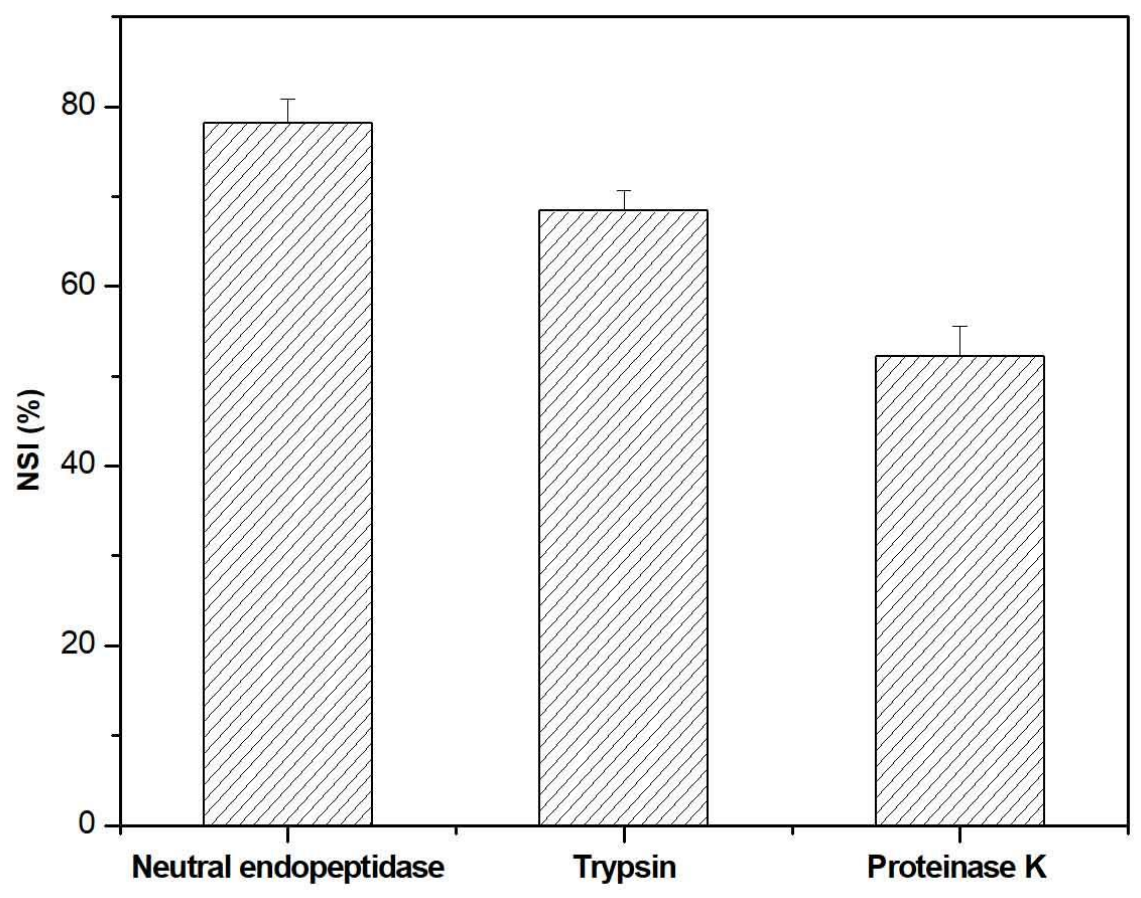

Fig. S1. Efficacy of enzymatic hydrolysis of different proteases; the enzyme dose was $10000 \mathrm{IU}$ per gram DSM and the average data of triplicate experiments is presented; error bars represented the standard deviation of triplicate experiments 